\title{
Awareness and knowledge of hepatitis $C$ among health care providers and the public: A scoping review
}

\author{
$\mathrm{SHa}^{1 *}, \mathrm{~K} \mathrm{Timmerman}^{1}$
}

\begin{abstract}
Background: The Global Viral Hepatitis Strategy aims to eliminate hepatitis as a public health threat by 2030. The hepatitis $\mathrm{C}$ virus (HCV) can be difficult to detect as infection can remain asymptomatic for decades. Individuals are often neither offered nor seek testing until symptoms develop. This highlights the importance of increasing awareness and knowledge among health care providers and the public to reach the viral hepatitis goals.
\end{abstract}

Objectives: To conduct a scoping review to characterize current awareness and knowledge among health care providers and the public regarding $\mathrm{HCV}$ infection, transmission, prevention and treatment and to identify knowledge gaps that public health action could address.

Methods: A literature search was conducted using Embase, Medline and Scopus to find studies published between January 2012 and July 2017. A search for grey literature was also undertaken. The following data were extracted: author, year of publication, study design, population, setting, country, method of data collection, and knowledge and awareness outcomes. Commentaries, letters to the editor and narrative reviews were excluded.

Results: Nineteen studies were included in this review. The definition of awareness and knowledge varied across studies; at times, these terms were used interchangeably. Health care providers identified injection drug use or blood transfusions as routes of HCV transmission more frequently than other routes of transmission such as tattooing with unsterile equipment and sexual transmission. Among the general public, misconceptions about HCV included believing that kissing and casual contact were routes of HCV transmission and that a vaccine to prevent $\mathrm{HCV}$ was available. Overall, there was a lack of data on other high-risk populations (e.g., Indigenous, incarcerated).

Conclusion: Continued public and professional education campaigns about HCV could help support HCV risk-based screening and testing. Future research could assess the awareness of other populations at increased risk and include consistent definitions of awareness and knowledge.

Suggested citation: Ha S, Timmerman K. Awareness and knowledge of hepatitis $\mathrm{C}$ among healthcare providers and the public: A scoping review. Can Commun Dis Rep 2018;44(7/8):157-65. https://doi.org/10.14745/ccdr. v44i78a02

Keywords: awareness, knowledge, hepatitis C, scoping review, health care providers

\section{Affiliation}

${ }^{1}$ Centre for Communicable Diseases and Infection Control, Public Health Agency of Canada, Ottawa, ON

*Correspondence: shalane.ha@ canada.ca

\section{Background}

Hepatitis $\mathrm{C}$ virus (HCV) causes inflammation of the liver, which can become chronic. Chronic HCV infection can be asymptomatic for decades before symptoms appear. Globally, about 71 million people have chronic HCV infection (1). Chronic $\mathrm{HCV}$ infection is not easy to detect; even when symptoms are present, they are often nonspecific (e.g., fatigue) (2). Chronic HCV infection can lead to cirrhosis or liver cancer. Approximately half a million people die each year from HCV-related liver diseases (3).
In 2011, about 220,000-246,000 individuals were living with chronic HCV infection in Canada and approximately 44\% were unaware of their infection (4). Over the past few years, there have been significant advances in HCV treatment, and infection is now curable. Previous treatment regimens consisted of peg-interferon and ribavirin, which involved longer treatment durations and more side effects. The new interferon-free direct acting antiviral (DAA) treatments have been found to be highly effective and have fewer side effects. Currently, most provincial and territorial formularies cover these new treatments and 
Canada has started to witness a decrease in hospitalizations associated with HCV infection and chronic liver disease (5).

In 2016, the 69th World Health Assembly adopted the Global Health Sector Strategy on Viral Hepatitis with the goal of eliminating both hepatitis $B$ and $C$ as a public health threat by 2030 (6). The goal is to have $90 \%$ of viral hepatitis B and $C$ diagnosed and $80 \%$ of eligible people with chronic hepatitis $B$ virus (HBV) and chronic HCV infection treated (6). Awareness and knowledge of hepatitis $C$ is an important first step in the elimination strategy. The identification of $\mathrm{HCV}$ through screening and testing is essential for patients to make appropriate lifestyle changes and to begin treatment.

Limited awareness of and knowledge about HCV have been identified as the key barriers to health care providers offering hepatitis $C$ testing and for patients seeking testing (7). This lack of awareness and knowledge leads to continued HCV transmission and missed prevention and treatment opportunities. In an effort to improve risk-based screening in Canada and to reduce the number of people who are unaware of their infection, it is important to understand current awareness and knowledge of HCV among health care providers and the public alike.

The objectives of this review are to summarize health care providers' and the general public's awareness and knowledge of the natural history of HCV and HCV transmission, prevention and treatment, and to identify knowledge gaps in both groups that public health action could address.

\section{Methods}

We worked with a research librarian to conduct a literature search in Embase, Medline and Scopus for published studies on awareness and knowledge of $\mathrm{HCV}$ among health care providers and the public. We also completed a search for grey literature (i.e., reports available on public domains) using Google. The following search terms were used: hepatitis $\mathrm{C}, \mathrm{HCV}$, awareness, and knowledge. Studies were included in the review if they were published between January 2012 and July 2017; published in English or French; conducted in Canada or similarly economically developed and well-resourced countries; and focused on the public or health care providers. We restricted the search years to the last five years to capture the most recent information. Commentaries, letters to editors and case studies were excluded. Outcomes of interest included HCV awareness and knowledge, which are defined in various ways based on the study.

After screening the titles and abstracts of potentially relevant articles, we reviewed the full texts of included studies. We developed data extraction forms and extracted data on the following: author, year of publication, study design, population, setting, country, method of data collection, and knowledge and awareness outcomes.

As a scoping review a qualitative analysis of the findings was completed and the results were summarized into themes but we did not conduct a detailed assessment of overall quality or risk of bias.

\section{Results}

The literature search identified 141 potentially relevant articles on HCV awareness and knowledge of health care providers and the general public. A manual search of the reference lists identified five additional references. An additional three reports were identified through the grey literature search. After the title and abstract screening and the full text review, 19 studies were included in this review (Figure 1).

\section{Figure 1: Flowchart of study selection process}

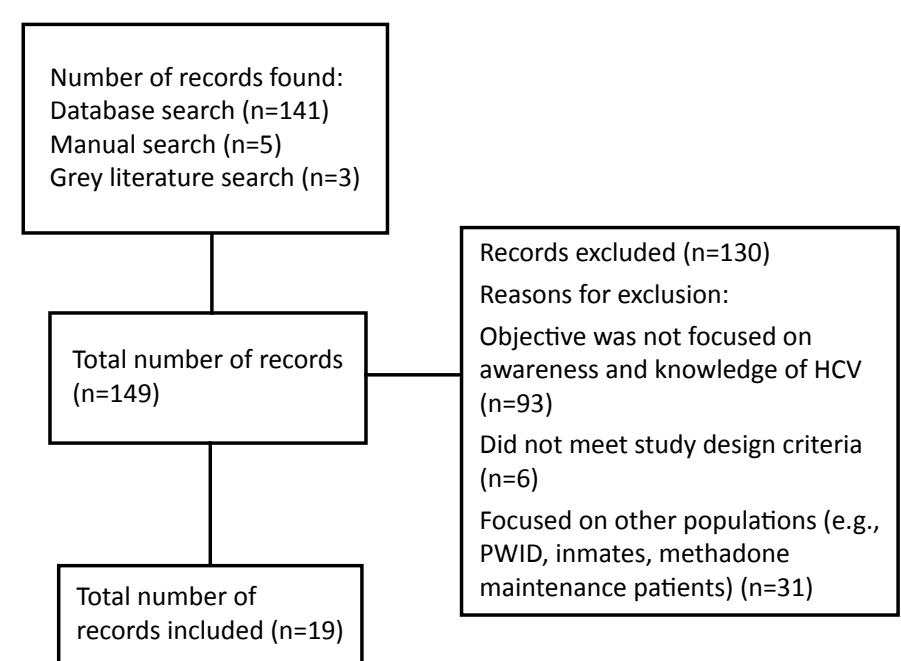

Abbreviations: $\mathrm{HCV}$, hepatitis $\mathrm{C}$ virus; $\mathrm{n}$, number; PWID, people who inject drugs

Awareness and knowledge were at times used interchangeably in the included studies. Awareness was defined as either awareness of one's own HCV infection, diagnosis or seropositivity or awareness of the existence of $\mathrm{HCV}$, the risk factors or availability of treatment. Knowledge could include the natural history and consequences of HCV, HCV risk factors and transmission routes, or vaccine and treatment availability. Consequently, the results are reported based on how the studies themselves defined awareness and knowledge.

\section{Characteristics of included studies}

The majority of the included studies were conducted in the United States (US; $n=8$ ), followed by Canada $(n=5)$ and Australia $(n=3)$. The remainder of the studies were from Germany, Italy, Japan and Netherlands. Most of the studies $(n=13)$ targeted the general population and less than one-third $(n=5)$ focused on health care providers; one study included both populations. Participants were recruited from a variety of settings including hospitals, outpatient clinics, primary care clinics, emergency departments and online panels. Data collection methods most often included questionnaires completed online, in-person or by phone. (For more details about the included studies, please refer to Appendix 1.)

Of the studies that focused on health care providers, job categories included physicians, nurses, residents, dental students and specialists (i.e., hepatologists and gastroenterologists). Of the studies that focused on non-health care providers, 
population groups included HCV-infected people with or without HIV coinfection, men who have sex with men (MSM), immigrants, the general public and adults born between 1945 and 1965

(Table 1).

\section{Table 1: Summary of included studies}

\begin{tabular}{|c|c|}
\hline Characteristics & Number of studies $(n)^{a}$ \\
\hline \multicolumn{2}{|l|}{ Country } \\
\hline US & 8 \\
\hline Canada & 5 \\
\hline Australia & 3 \\
\hline Netherlands & 2 \\
\hline Germany & 1 \\
\hline Italy & 1 \\
\hline Japan & 1 \\
\hline Other & 3 \\
\hline \multicolumn{2}{|l|}{ Health care providers } \\
\hline Physicians & 3 \\
\hline Nurses & 3 \\
\hline $\begin{array}{l}\text { Specialists (e.g., hepatologist, } \\
\text { gastroenterologist) }\end{array}$ & 2 \\
\hline Medical students & 1 \\
\hline Other & 1 \\
\hline \multicolumn{2}{|l|}{ Non-health care providers } \\
\hline $\begin{array}{l}\text { People living with HCV with or without } \\
\text { HIV coinfection }\end{array}$ & 4 \\
\hline Men who have sex with men (MSM) & 3 \\
\hline General public & 2 \\
\hline People born between 1945-1965 & 2 \\
\hline Immigrants & 1 \\
\hline Other & 1 \\
\hline
\end{tabular}

Abbreviations: $\mathrm{HCV}$, hepatitis $\mathrm{C}$ virus; HIV, human immunodeficiency virus

a Some studies included more than one population or country

\section{Awareness}

There were six studies on awareness of hepatitis C $(11,12,14,17,18,24)$. The types of awareness varied across these studies: awareness of risk factors, of treatment, of one's own infection and of the existence of HCV. Four studies included findings on awareness of HCV by the general public $(11,12$, $14,17)$, one on awareness of HCV by MSM (18) and one on awareness of treatment by Canadian health care providers (24).

Two studies found that the general public had some awareness (defined as the knowledge that something exists) of hepatitis $\mathrm{C}$ $(11,17)$. Compared with the public $(27 \%)$, Canadian-born baby boomers (33\%) were more likely to be aware that injection drug users have an increased risk of HCV compared with the general public (27\%) (14). However, results from the United States' National Health and Nutrition Examination Survey (NHANES) indicated that fewer than half of Americans who had HCV infection were aware of their infection (12). Two studies found that the general public was not clear about the differences between hepatitis $A, B$ and $C(11,19)$.

\section{Knowledge}

All of the included studies assessed knowledge of HCV. Knowledge was measured using a series of yes/no/don't know or true/false statements, or one's perceived knowledge level. Knowledge was assessed in the following topics: natural history of $\mathrm{HCV}$, transmission routes, the availability of a vaccine and the availability of treatment.

\section{The natural history of HCV and its consequences}

Three studies included information on health care providers' knowledge of the natural history and consequences of HCV $(16,25,26)$. In a convenience study of Canadian physicians, $35 \%$ reported "knowing a lot" about symptoms associated with HCV (16). In a small study of dental students from Bulgaria, $80 \%$ reported knowing that infection with hepatitis $B$ virus (HBV) or HCV may be asymptomatic (26). In addition, residents, physicians, nurse practitioners and physician assistants working in emergency departments in the US were reported to have high knowledge scores regarding the manifestations of HCV (percentage not reported) (25).

Eight studies included information on the public's knowledge about the natural history of $\operatorname{HCV}(8,9,11,13,14,16,17,19)$. Two Canadian studies found that $83-90 \%$ of participants knew that people with HCV could be unaware of an existing infection $(14,16)$. Similarly, over half $(57 \%)$ of US baby boomers knew that $\mathrm{HCV}$ can lead to liver cancer and $61 \%$ believed that someone with HCV infection can present with no symptoms (8). One study reported that one-third of MSM knew that HCV infection could lead to liver cancer (31\%) and liver failure (37\%)(18). Conversely, in an international study with immigrants from Asia, it was reported that there was confusion about the different types of hepatitis infections and uncertainty about the natural history of the infection (19).

\section{Knowledge of transmission}

Two studies reported on health care providers' knowledge of HCV transmission $(22,26)$. The majority of health care providers in the studies identified the main routes of transmission as blood transfusions, exposure to blood during sexual activity and sharing needles while injecting drugs $(22,26)$. A small percentage $(12 \%)$ of nurses working in hemodialysis clinics in Italy believed, incorrectly, that HCV can be transmitted through kissing, and $19 \%$ did not know that getting a tattoo could be a means of HCV transmission (22).

Ten studies reported information on knowledge of HCV transmission among the general public $(8,10-12,14-17,19,21)$. One Canadian study reported that the most frequently known $\mathrm{HCV}$ transmission routes were blood transfusions, unsafe/ unprotected intercourse and injection drug use/sharing of needles (14). Few Canadians identified other routes of transmission such as sharing personal hygiene items (7\%), getting tattoos and body piercings (4\%), exposure to risk factors while travelling in foreign countries where HCV may be endemic (4\%), and mother-to-child transmission through pregnancy (1\%) (14). Furthermore, approximately $54-62 \%$ of the general population in Canada knew that HCV is transmitted mainly through blood-to- 
blood contact (16). In four studies, a small percentage of the general public indicated that HCV can be transmitted through kissing or casual contact $(8,12,14,21)$.

\section{Knowledge of treatment}

Two recent studies, published after the new interferon-free DAA therapies became available, focused on knowledge of the curability of $\operatorname{HCV}(8,24)$.

Among health care providers, specialists (i.e., hepatologists, gastroenterologists, hepatology nurses) scored higher on knowledge statements about HCV treatment than general practitioners (GPs) $(23,24)$. Of the 10 primary care physicians surveyed, seven were unsure or not aware of the new interferon-free DAAs and were not sure about the mechanisms of action (24).

In the US, $51 \%$ of baby boomers presenting to emergency departments correctly believed that HCV is curable and $77 \%$ had knowledge of new medications available to treat HCV (8). However, three studies detected a misconception among the general public about the availability of a vaccine to prevent $\mathrm{HCV}$ $(11,15,21)$. About one half of the Canadians interviewed $(50 \%)$ in one study believed there was a vaccine to prevent HCV (14). In two US studies, $42 \%$ of American baby boomers and $60 \%$ of African-American baby boomers believed there was a vaccine to prevent $\mathrm{HCV}(8,11)$.

A summary of the findings is shown in Table 2.

Table 2: Summary of findings on awareness and knowledge of hepatitis $C$ virus among health care professionals and the general public

\begin{tabular}{|l|l|}
\hline Outcomes & \multicolumn{1}{c|}{ Key Findings } \\
\hline Awareness & $\begin{array}{l}\text { Public: } \\
\text { The general public was aware of HCV and main risk } \\
\text { factors (14) } \\
\text { MSM had high awareness of HCV treatment (18) }\end{array}$ \\
\hline Knowledge & $\begin{array}{l}\text { Health care providers: } \\
\text { Specialists were more up-to-date on new HCV } \\
\text { treatments than primary care physicians (24) } \\
\text { Health care providers knew less about some routes } \\
\text { of HCV transmission (e.g. unsafe tattooing practices } \\
\text { or piercings) compared with the main routes (i.e., } \\
\text { injection drug use) (22,26) }\end{array}$ \\
\cline { 2 - 2 } & $\begin{array}{l}\text { Public: } \\
\text { The general public had misconceptions around risk } \\
\text { factors for transmission of hepatitis C (e.g., casual } \\
\text { contact, saliva, kissing) (11,12,14,16,19) } \\
\text { There were also misconceptions about the availability } \\
\text { of a vaccine (8,14,16) } \\
\text { Overall, there was little knowledge about the } \\
\text { interferon-free DAA hepatitis C treatment } \\
\text { (8,9,13,14,16) }\end{array}$ \\
\hline
\end{tabular}

Abbreviations: DAA, direct acting antivirals; $\mathrm{HCV}$, hepatitis $\mathrm{C}$ virus; MSM, men who have sex with men

\section{Discussion}

To the best of our knowledge, this is the first scoping review that provides a snapshot of what health care providers and the general public know about HCV. Overall, health care providers know about the most common transmission routes and risk factors, whereas specialists are more up-to-date on treatments than primary care physicians $(23,24)$. The general public is aware of HCV; however, some people do not know the difference between hepatitis $A, B$ and $C$; there are misconceptions around routes of transmission; and some incorrectly believe that an HCV-preventable vaccine exists.

There are some limitations to consider when interpreting our findings. First, there was a lack of standard definitions for knowledge and awareness and the terms were often used interchangeably. Second, only a few studies captured awareness and knowledge of interferon-free DAA treatments. Finally, the findings were based on cross-sectional studies, which only capture data of a study population at a single point in time.

Future research could include assessment of high-risk populations (e.g., Indigenous peoples or incarcerated populations); incorporate clear and consistent definitions of awareness and knowledge; and assess factors that may be associated with differences in awareness and knowledge (e.g., rural versus urban settings, and socioeconomic status). Additional research on health care providers' knowledge of HCV could also help tailor future knowledge translation and exchange products.

In conclusion, increasing health care providers' and the general public's awareness of and knowledge about HCV can facilitate the discussion about whether HCV testing should be considered. The findings and gaps identified in this review can help inform future interventions and public health campaigns to do with HCV and support the Global Health Sector Strategy on Viral Hepatitis.

\section{Authors' statement}

$\mathrm{SH}$ - Conceptualization, methodology, writing (final draft), data curation, validation, formal analysis, writing, reviewing and editing, supervision, project administration, visualization KT-Conceptualization, methodology, reviewing and editing, supervision, project administration, visualization

\section{Conflict of interest}

None.

\section{Acknowledgements}

We would like to thank Dr. Margaret Gale-Rowe and Dr. Jun Wu for their contributions to the conceptualization and revision of this manuscript, Audréanne Garand for her support in the data collection, extraction and initial analysis of the results, and the Health Canada librarian who helped conduct the literature search. 


\section{Funding}

This work was supported by the Public Health Agency of Canada.

\section{References}

1. World Health Organization. Hepatitis C: key facts. Geneva: World Health Organization; 2017. http://www.who.int/en/news-room/factsheets/detail/hepatitis-c

2. Westbrook RH, Dusheiko G. Natural history of hepatitis C. J Hepatol 2014 Nov;61(1 Suppl):S58-68. http://dx.doi.org/10.1016/j. jhep.2014.07.012. PubMed (https://www.ncbi.nlm.nih.gov/ pubmed/25443346)

3. World Health Organization. Global hepatitis report, 2017. Geneva: World Health Organization; 2017. http://apps.who.int/iris/bitstream/ handle/10665/255016/9789241565455-eng.pdf?sequence=1

4. Trubnikov M, Yan P, Archibald C. Estimated prevalence of hepatitis C virus infection in Canada, 2011. Can Commun Dis Rep 2014 Dec;40(19):429-36. PubMed (https://www.ncbi.nlm.nih.gov/ pubmed/29769874)

5. Schanzer D, Pogany L, Aho J, Tomas K, Gale-Rowe M, Kwong J, Janjua NZ, Feld J. Impact of availability of direct-acting antivirals for hepatitis C on Canadian hospitalization rates, 2012-2016. Can Commun Dis Rep 2018:44(7/8):150-6. https://www.canada.ca/en/ public-health/services/reports-publications/canada-communicabledisease-report-ccdr/monthly-issue/2018-44/issue-7-8-july-5-2018/ article-1-canadian-hospitalization-rates-hep-c.html

6. World Health Organization. Global Health Sector Strategy on Viral Hepatitis 2016-2021: towards ending viral hepatitis. Geneva: World Health Organization; 2016. http://apps.who.int/iris/ bitstream/10665/246177/1/WHO-HIV-2016.06-eng.pdf?ua=1

7. McLeod A, Cullen BL, Hutchinson SJ, Roy KM, Dillon JF, Stewart EA, Goldberg DJ. Limited impact of awareness-raising campaigns on hepatitis $C$ testing practices among general practitioners. J Viral Hepat 2017 Nov;24(11):944-54. http://dx. doi. org/10.1111/jvh.12724. PubMed (https://www.ncbi.nlm.nih.gov/ pubmed/28502088)

8. Allison WE, Chiang W, Rubin A, Oshva L, Carmody E. Knowledge about hepatitis $C$ virus infection and acceptability of testing in the 1945-1965 birth cohort (baby boomers) presenting to a large urban emergency department: a pilot study. J Emerg Med 2016 Jun;50(6):825-831.e2. http://dx.doi.org/10.1016/j. jemermed.2016.02.001. PubMed (https://www.ncbi.nlm.nih.gov/ pubmed/26954104)

9. CATIE. Room for improvement: knowledge exchange needs of people living with hepatitis C. Toronto: CATIE; 2015. http:// www.catie.ca/sites/default/files/Hepatitis\%20C\%20needs\%20 assessment\%20report_final.pdf

10. Chen EY, North CS, Fatunde O, Bernstein I, Salari S, Day B, Jain MK. Knowledge and attitudes about hepatitis $\mathrm{C}$ virus (HCV) infection and its treatment in $\mathrm{HCV}$ mono-infected and HCV/HIV co-infected adults. J Viral Hepat 2013 Oct;20(10):708-14. http://dx.doi. org/10.1111/jvh.12095. PubMed (https://www.ncbi.nlm.nih.gov/ pubmed/24010645)

11. Crutzen R, Göritz AS. Public awareness and practical knowledge regarding Hepatitis $A, B$, and C: a two-country survey. J Infect Public Health 2012 Apr;5(2):195-8. http://dx.doi.org/10.1016/j. jiph.2011.12.001. PubMed (https://www.ncbi.nlm.nih.gov/ pubmed/22541268/)

12. Denniston MM, Klevens RM, McQuillan GM, Jiles RB. Awareness of infection, knowledge of hepatitis $C$, and medical follow-up among individuals testing positive for hepatitis C: National Health and Nutrition Examination Survey 2001-2008. Hepatology 2012 Jun;55(6):1652-61. http://dx.doi.org/10.1002/hep.25556. PubMed (https://www.ncbi.nlm.nih.gov/pubmed/22213025)
13. Eguchi H, Wada K. Knowledge of HBV and HCV and individuals' attitudes toward HBV- and HCV-infected colleagues: a national cross-sectional study among a working population in Japan. PLoS One 2013 Sep;8(9):e76921. http://dx.doi.org/10.1371/ journal.pone.0076921. PubMed (https://www.ncbi.nlm.nih.gov/ pubmed/24086765)

14. EKOS Research Associates Inc. 2012 HIV/AIDS attitudinal tracking survey. Ottawa: EKOS; 2012 Oct. http://www.catie.ca/sites/default/ files/2012-HIV-AIDS-attitudinal-tracking-survey-final-report.pdf

15. Hopwood M, Lea T, Aggleton P. Multiple strategies are required to address the information and support needs of gay and bisexual men with hepatitis C in Australia. J Public Health (Oxf) 2016 Mar;38(1):156-62. http://dx.doi.org/10.1093/pubmed/fdv002. PubMed (https://www.ncbi.nlm.nih.gov/pubmed/25626415)

16. Ipsos Healthcare. Survey on hepatitis $C$ knowledge and perception among Canadians and GP, September 2012. Paris: Ipsos; 2012. https://www.ipsos.com/sites/default/files/publication/2013-01/5977report.pdf

17. Lambers FA, Prins M, Davidovich U, Stolte IG. High awareness of hepatitis $\mathrm{C}$ virus (HCV) but limited knowledge of $\mathrm{HCV}$ complications among HIV-positive and HIV-negative men who have sex with men. AIDS Care 2014 Apr;26(4):416-24. http://dx.doi.org/10.1080/0 9540121.2013.832721. PubMed (https://www.ncbi.nlm.nih.gov/ pubmed/24024525)

18. Lea T, Hopwood M, Aggleton P. Hepatitis $C$ knowledge among gay and other homosexually active men in Australia. Drug Alcohol Rev 2016 Jul;35(4):477-83. http://dx.doi.org/10.1111/dar.12333. PubMed (https://www.ncbi.nlm.nih.gov/pubmed/26369759)

19. Owiti JA, Greenhalgh T, Sweeney L, Foster GR, Bhui KS. Illness perceptions and explanatory models of viral hepatitis $B \& C$ among immigrants and refugees: a narrative systematic review. BMC Public Health 2015 Feb;15:151. http://dx.doi.org/10.1186/s12889-0151476-0. PubMed (https://www.ncbi.nlm.nih.gov/pubmed/25886390)

20. Pundhir P, North CS, Fatunde O, Jain MK. Health beliefs and co-morbidities associated with appointment-keeping behavior among HCV and HIV/HCV patients. J Community Health 2016 Feb;41(1):30-7. http://dx.doi.org/10.1007/s10900-015-0059-4. PubMed (https://www.ncbi.nlm.nih.gov/pubmed/26179172)

21. Rashrash ME, Maneno MK, Wutoh AK, Ettienne EB, Daftary MN. An evaluation of hepatitis $C$ knowledge and correlations with health belief model constructs among African American "baby boomers". J Infect Public Health 2016 Jul-Aug;9(4):436-42. http://dx. doi. org/10.1016/j.jiph.2015.11.005. PubMed (https://www.ncbi.nlm.nih. gov/pubmed/26706773)

22. Bianco A, Bova F, Nobile CG, Pileggi C, Pavia M; Collaborative Working Group. Healthcare workers and prevention of hepatitis $C$ virus transmission: exploring knowledge, attitudes and evidence-based practices in hemodialysis units in Italy. BMC Infect Dis 2013 Feb;13(76):76. http://dx.doi.org/10.1186/1471-2334-13-76. PubMed (https://www.ncbi.nlm.nih.gov/pubmed/23391009)

23. McGowan CE, Monis A, Bacon BR, Mallolas J, Goncales FL, Goulis I, Poordad F, Afdhal N, Zeuzem S, Piratvisuth T, Marcellin P, Fried MW. A global view of hepatitis C: physician knowledge, opinions, and perceived barriers to care. Hepatology 2013 Apr;57(4):1325-32. http://dx.doi.org/10.1002/hep.26246. PubMed (https://www.ncbi. nlm.nih.gov/pubmed/23315914)

24. Naghdi R, Seto K, Klassen C, Emokpare D, Conway B, Kelley M, Yoshida E, Shah HA. A hepatitis $C$ educational needs assessment of Canadian healthcare providers. Can J Gastroenterol Hepatol 2017 10:1-10. https://doi.org/10.1155/2017/5324290

25. Rotte M, O'Donnell R. Knowledge, beliefs, and attitudes of emergency department health care providers towards hepatitis $C$ and rapid hepatitis C testing. Ann Emerg Med 2013;62(4):S103. http://dx.doi.org/10.1016/j.annemergmed.2013.07.108

26. Todorova TT, Tsankova G, Tsankova D, Kostadinova T, Lodozova N. Knowledge and attitude towards hepatitis $B$ and hepatitis $C$ among dental medicine students. J of IMAB 2015;21(3):810-3. http://dx.doi. org/10.5272/jimab.2015213.810 
Appendix 1: Description of included studies $(n=19)$

\begin{tabular}{|c|c|c|c|}
\hline $\begin{array}{c}\text { Author(s), year } \\
\text { of publication / } \\
\text { Country }\end{array}$ & $\begin{array}{c}\text { Study design / } \\
\text { Population / setting }\end{array}$ & $\begin{array}{l}\text { Method of data } \\
\text { collection }\end{array}$ & Outcome / Findings \\
\hline \multicolumn{4}{|c|}{ General public $(n=14)$} \\
\hline $\begin{array}{l}\text { Allison et al. (2016) } \\
\text { (8) } \\
\text { US }\end{array}$ & $\begin{array}{l}\text { Cross-sectional study } \\
\text { Baby boomers } \\
(1945-1965)(n=915) \\
\text { Urban emergency } \\
\text { department }\end{array}$ & $\begin{array}{l}\text { Structured interview } \\
\text { within six weeks of } \\
\text { HCV antibody test to } \\
\text { assess knowledge }\end{array}$ & $\begin{array}{l}\text { Knowledge } \\
\text { - Most participants were familiar with the natural history and } \\
\text { complications of HCV } \\
\text { - Most participants were familiar with the risk factors for HCV } \\
\text { - } \text { kome participants had misconceptions about transmission (i.e., } \\
\text { - More than half of participants thought that HCV-preventable vaccines } \\
\text { - Many lacked the knowledge about the curability of HCV }\end{array}$ \\
\hline $\begin{array}{l}\text { CATIE (2015) (9) } \\
\text { Canada }\end{array}$ & $\begin{array}{l}\text { Cross-sectional study } \\
\text { People living with HCV } \\
(\mathrm{n}=326) \\
\text { Medical clinics offering } \\
\text { HCV infection care }\end{array}$ & $\begin{array}{l}\text { Self-administered } \\
\text { questionnaire (paper } \\
\text { and online) }\end{array}$ & $\begin{array}{l}\text { Knowledge } \\
\text { - } 23 \% \text { reported knew a lot about hepatitis C } \\
\text { - Younger respondents, men and Indigenous people were more likely } \\
\text { to report lower levels of knowledge about hepatitis C } \\
\text { - } 20 \% \text { reported knowing a lot about treatment } \\
\text { - Younger respondents and Indigenous people were more likely to } \\
\text { report lower levels of knowledge about hepatitis C }\end{array}$ \\
\hline $\begin{array}{l}\text { Chen et al. (2013) } \\
\text { (10) } \\
\text { US }\end{array}$ & $\begin{array}{l}\text { Cross-sectional study } \\
\text { HCV infection and } \\
\text { HIV/HCV coinfection } \\
(n=292) \\
\text { Outpatient clinic }\end{array}$ & $\begin{array}{l}\text { Cross-sectional survey } \\
\text { and pre- and post- } \\
\text { educational surveys }\end{array}$ & $\begin{array}{l}\text { Knowledge } \\
\text { - Overall, HCV knowledge was limited, with less than } 50 \% \text { of the } \\
\text { - } \text { Noestions answered correctly } \\
\text { regarding HCV knowledge score or the subscales representing HCV } \\
\text { disease and transmission } \\
\text { - Coinfected participants had a higher mean HCV treatment knowledge } \\
\text { score compared with mono-infected participants }\end{array}$ \\
\hline $\begin{array}{l}\text { Crutzen \& Goritz } \\
(2012)(11) \\
\text { Germany and } \\
\text { Netherlands }\end{array}$ & $\begin{array}{l}\text { Cross-sectional study } \\
\text { General public in } \\
\text { Germany }(n=1989) \text { and } \\
\text { Netherlands }(n=668) \\
\text { Online panel }\end{array}$ & $\begin{array}{l}\text { Two large-scale } \\
\text { surveys administered } \\
\text { to online panels }\end{array}$ & $\begin{array}{l}\text { Awareness } \\
\text { - High awareness of hepatitis A, B and C (no percentage values/scales } \\
\text { provided) } \\
\text { Knowledge } \\
\text { - Knowledge was very low in both countries (slightly above } 50 \% \text { correct } \\
\text { answers) } \\
\text { - People are aware of the existence of similarities and differences } \\
\text { between HAV, HBV and HCV, but they know less about the } \\
\text { transmission, consequences and prevention of these infections }\end{array}$ \\
\hline $\begin{array}{l}\text { Denniston et al. } \\
(2012)(12) \\
\text { US }\end{array}$ & $\begin{array}{l}\text { Cross-sectional study } \\
\text { General public who } \\
\text { tested positive for HCV } \\
\text { (n=32,847) } \\
\text { NHANES 2001-2008 } \\
\text { data }\end{array}$ & Phone interview & $\begin{array}{l}\text { Awareness } \\
\text { - Less than half of those who were HCV-positive were aware of their } \\
\text { infection } \\
\text { Knowledge } \\
\text { - Respondents answered most knowledge questions correctly, ranging } \\
\text { from } 57.1 \% \text { to } 95.7 \% \text { correct } \\
\text { - Lower proportion of respondents correctly answered questions } \\
\text { related to the transmission of HCV through kissing, sexually and } \\
\text { vertically (i.e. mother to child) } \\
\text { - Responses about vertical transmission had the highest proportion of } \\
\text { "don't know" responses ( } 33.7 \%)\end{array}$ \\
\hline $\begin{array}{l}\text { Eguchi \& Wada } \\
(2013)(13) \\
\text { Japan }\end{array}$ & $\begin{array}{l}\text { Cross-sectional study } \\
\text { Japanese working } \\
\text { population }(n=3,129) \\
\text { Online }\end{array}$ & $\begin{array}{l}\text { Self-administered } \\
\text { questionnaire (online) }\end{array}$ & $\begin{array}{l}\text { Knowledge } \\
\text { - } 19 \% \text { believed that HBV/HCV is the cause of liver cancer in } 90 \% \text { of } \\
\text { cases } \\
\text { - } 39 \% \text { believed that people who have HBV/HCV may develop hepatic } \\
\text { cirrhosis or liver cancer at age } 40-60 \text { years } \\
\text { - } 39 \% \text { believed that treatment can cure HBV/HCV and prevent liver } \\
\text { damage }\end{array}$ \\
\hline
\end{tabular}




\begin{tabular}{|c|c|c|c|}
\hline $\begin{array}{c}\text { Author(s), year } \\
\text { of publication / } \\
\text { Country }\end{array}$ & $\begin{array}{c}\text { Study design / } \\
\text { Population / setting }\end{array}$ & $\begin{array}{l}\text { Method of data } \\
\text { collection }\end{array}$ & Outcome / Findings \\
\hline \multicolumn{4}{|c|}{ General public $(n=14)$ (continued) } \\
\hline $\begin{array}{l}\text { EKOS Research } \\
\text { Associates Inc. } \\
(2012)(14) \\
\text { Canada }\end{array}$ & $\begin{array}{l}\text { Cross-sectional study } \\
\text { General public ( } \geq 16 \\
\text { years old) } \\
\text { ( } n=2,000) \\
\text { Survey panel }\end{array}$ & Phone interview & $\begin{array}{l}\text { Awareness and knowledge } \\
\text { - } \quad \text { Awareness was not clearly defined } \\
\text { - } 23 \% \text { of Canadians believed they are very knowledgeable about HCV } \\
\text { - } 50 \text { ave no response } \\
\text { - } \mathrm{know} \text { /gave no response } \\
\text { - } 36 \% \text { indicated that HCV can be transmitted through blood } \\
\text { transfusions } \\
\text { - } 25 \% \text { indicated that HCV can be transmitted through unsafe/ } \\
\text { unprotected intercourse } \\
\text { - } 23 \% \text { indicated that HCV can be transmitted through injection drug } \\
\text { - } \quad<10 \% \text { indicated that } \mathrm{HCV} \text { can be transmitted the following ways: } \\
\text { casual contact (e.g., kissing, hugging, shaking hands); from mother } \\
\text { to child during pregnancy; tattoos, body piercing; sharing personal } \\
\text { - hygiene items } \\
25 \% \text { did not know/had no response of how HCV can be transmitted }\end{array}$ \\
\hline $\begin{array}{l}\text { Hopwood et al. } \\
(2016)(15) \\
\text { Australia }\end{array}$ & $\begin{array}{l}\text { Cross-sectional study } \\
\text { Gay and bisexual men } \\
\text { living with HIV and/or } \\
\text { HCV ( } n=474) \\
\text { Online study }\end{array}$ & $\begin{array}{l}\text { Self-administered } \\
\text { questionnaire }\end{array}$ & $\begin{array}{l}\text { Knowledge } \\
\text { - HCV knowledge was moderate to good } \\
\text { - } 44 \% \text { believed that being HIV positive makes it more likely to get HCV } \\
\text { during sex between men } \\
\text { - } \text { Respondents wanted information on how to avoid transmitting HCV } \\
\text { to sexual partners ( } 46 \%) \text {; complementary therapies for HCV (42\%); } \\
\text { how HIV/HCV coinfection affects health (42\%); and how HIV and HCV } \\
\text { treatments affect each other ( } 40 \%) \\
\text { - The majority of men said their GP or specialist (85\%) or the Internet } \\
\text { (69\%) were their primary sources of HCV information. Fewer } \\
\text { men reported that they had accessed information via hepatitis } \\
\text { organizations (52\%); other health care workers (38\%); and friends } \\
\text { (23\%) }\end{array}$ \\
\hline $\begin{array}{l}\text { Ipsos (2012) (16) } \\
\text { Canada }\end{array}$ & $\begin{array}{l}\text { Cross-sectional study } \\
\text { General population } \\
\text { ( } \geq 18 \text { years) }(n=1,000) \\
\text { (Setting unknown: } \\
\text { information not } \\
\text { available) }\end{array}$ & $\begin{array}{l}\text { Self-administered } \\
\text { questionnaire (online) }\end{array}$ & $\begin{array}{l}\text { Knowledge } \\
\text { - } 90 \% \text { indicated that someone can have hepatitis } \mathrm{C} \text { and not know it } \\
\text { - } 62 \% \text { of Gen } \mathrm{Y}(18-29 \text { years), } 60 \% \text { of Gen X ( } 30-46 \text { years) and } 54 \% \text { of } \\
\text { baby boomers ( } 47-67 \text { years) knew that HCV is primarily transmitted } \\
\text { via blood-to-blood contact } \\
\text { - } 23 \% \text { of Gen Y ( } 18-29 \text { years), } 14 \% \text { of Gen X (30-46 year) and } 18 \% \text { of } \\
\text { baby boomers ( } 47-67 \text { years) knew of the curability of HCV infection }\end{array}$ \\
\hline $\begin{array}{l}\text { Lambers et al. } \\
(2013)(17) \\
\text { Netherlands }\end{array}$ & $\begin{array}{l}\text { Observational study } \\
\text { HIV-positive and } \\
\text { HIV-negative MSM } \\
\text { (n=539) } \\
\text { Various (recruitment } \\
\text { campaigns, media, } \\
\text { word of mouth) }\end{array}$ & $\begin{array}{l}\text { Self-administered } \\
\text { questionnaire (paper) }\end{array}$ & $\begin{array}{l}\text { Awareness } \\
\text { - } 74.1 \% \text { of respondents were aware that HCV can be transmitted } \\
\text { during sex between men; } 47.2 \% \text { were aware that HIV-positive men } \\
\text { are more likely to report HCV sexual transmission } \\
\text { - } 57.5 \% \text { were aware that there is treatment for HCV; } 35.6 \% \text { were aware } \\
\text { that HCV treatment could cure the infection } \\
\text { - } 23.0 \% \text { were aware of spontaneous clearance of HCV without } \\
\text { treatment } \\
\text { Knowledge } \\
\text { - Participants had the highest knowledge scores for HCV transmission } \\
\text { - Pard HIV/HCV coinfection } \\
\text { Prevention, and treatment }\end{array}$ \\
\hline
\end{tabular}


Appendix 1: Description of included studies $(n=19)$ (continued)

\begin{tabular}{|c|c|c|c|}
\hline $\begin{array}{c}\text { Author(s), year } \\
\text { of publication / } \\
\text { Country }\end{array}$ & $\begin{array}{l}\text { Study design / } \\
\text { Population / setting }\end{array}$ & $\begin{array}{l}\text { Method of data } \\
\text { collection }\end{array}$ & Outcome / Findings \\
\hline \multicolumn{4}{|c|}{ General public $(n=14)$ (continued) } \\
\hline $\begin{array}{l}\text { Lea et al. (2016) } \\
\text { (18) } \\
\text { Australia }\end{array}$ & $\begin{array}{l}\text { Cross-sectional study } \\
\text { MSM ( } \mathrm{n}=405) \\
\text { Various (social media } \\
\text { advertisements, } \\
\text { community } \\
\text { organization websites) }\end{array}$ & $\begin{array}{l}\text { Self-administered } \\
\text { questionnaire (online) }\end{array}$ & $\begin{array}{l}\text { Awareness } \\
\text { - } 70 \% \text { of HIV-negative and } 80 \% \text { of HIV-positive MSM were aware of } \\
\text { HCV } \\
\text { - More than half of HIV-negative ( } 55 \% \text { ) and HIV-positive MSM (63\%) } \\
\text { were aware of the existence of HCV treatment } \\
\text { Knowledge } \\
\text { - } 31 \% \text { knew that HCV could lead to liver cancer } \\
\text { - } 37 \% \text { believed that HCV could lead to liver failure }\end{array}$ \\
\hline $\begin{array}{l}\text { Owiti et al. (2015) } \\
\text { (19) } \\
\text { Australia, Canada, } \\
\text { Mexico, the } \\
\text { Netherlands, US }\end{array}$ & $\begin{array}{l}\text { Systematic narrative } \\
\text { review } \\
\text { Predominantly Asian } \\
\text { immigrants } \\
(\mathrm{n}=51)^{\mathrm{a}} \\
\text { (Setting unknown: } \\
\text { information not } \\
\text { available) }\end{array}$ & $\begin{array}{l}\text { Information not } \\
\text { available }\end{array}$ & $\begin{array}{l}\text { Knowledge } \\
\text { - There were misconceptions regarding the different types of hepatitis } \\
\text { (A, B, C) } \\
\text { - There was uncertainty around the natural history of hepatitis (e.g., } \\
\text { liver damage) and confusion about cause (hormones, stress) } \\
\text { - One of the studies reviewed reported lack of knowledge of effective } \\
\text { - HCV treatment } \\
\text { - There was low level of knowledge of main transmission risk factors, } \\
\text { especially sexual contact (horizontal transmission) and childbirth } \\
\text { (vertical transmission) } \\
\text { - Cause and transmission were incorrectly attributed principally to } \\
\text { lifestyle activities and cultural practices around food }\end{array}$ \\
\hline $\begin{array}{l}\text { Pundhir et al. } \\
\text { (2016) (20) } \\
\text { US }\end{array}$ & $\begin{array}{l}\text { Cross-sectional study } \\
\text { Patients ( } \geq 18 \text { years) } \\
\text { with HCV infection and } \\
\text { with or without HIV } \\
\text { coinfection ( } n=292 \text { ) } \\
\text { Primary care clinic }\end{array}$ & $\begin{array}{l}\text { Self-administered } \\
\text { questionnaire (online } \\
\text { and paper) }\end{array}$ & $\begin{array}{l}\text { Knowledge } \\
\text { - Respondents believed that if their doctor does not talk about } \\
\text { hepatitis C, it must not be important to treat } \\
\text { - Respondents perceived long wait times to see a specialist for } \\
\text { treatment as indicating that it was not important to treat } \\
\text { - HCV knowledge was not associated with appointment-keeping } \\
\text { behaviour }\end{array}$ \\
\hline $\begin{array}{l}\text { Rashrash et al. } \\
(2016)(21) \\
\text { US }\end{array}$ & $\begin{array}{l}\text { Cross-sectional study } \\
\text { African-American baby } \\
\text { boomers } \\
\text { (b. 1945-1965) ( } n=137) \\
\text { Hospital and wellness } \\
\text { centre }\end{array}$ & $\begin{array}{l}\text { Cross-sectional } \\
\text { survey using audio } \\
\text { computer-assisted } \\
\text { self-interviewing }\end{array}$ & 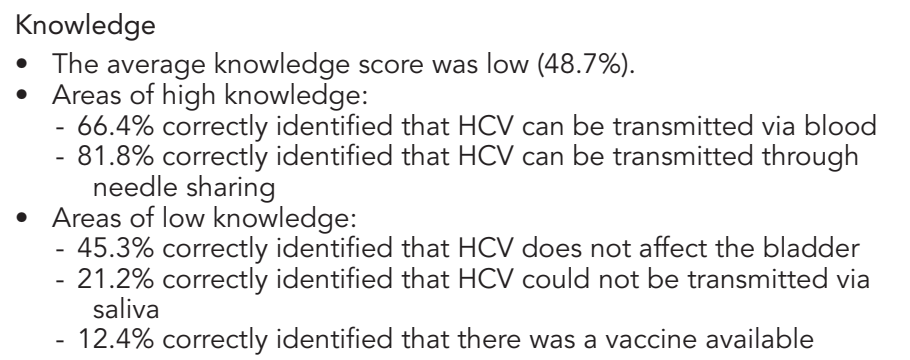 \\
\hline \multicolumn{4}{|c|}{ Health care providers $(n=6)$} \\
\hline $\begin{array}{l}\text { Bianco et al. (2013) } \\
\text { (22) } \\
\text { Italy }\end{array}$ & $\begin{array}{l}\text { Cross-sectional study } \\
\text { Nurses }(n=326) \\
\text { Hemodialysis units }\end{array}$ & $\begin{array}{l}\text { Self-administered } \\
\text { questionnaire }\end{array}$ & $\begin{array}{l}\text { Knowledge } \\
\text { - } 49.8 \% \text { correctly identified all modes of HCV transmission } \\
\text { - Most nurses correctly identified the following certain transmission } \\
\text { routes: receiving blood transfusion from an infected donor }(93.9 \%) \text {; } \\
\text { having sex with an HCV-positive partner }(91.4 \%) \text {; and sharing needles } \\
\text { - while injecting drugs }(90.7 \%) \\
\text { - } 11.5 \% \text { believed that HCV could be transmitted through kissing } \\
\text { tr.2\% did not indicate that getting a tattoo was a mode of } \\
\text { - } 21.4 \% \text { incorrectly believed that avoiding breastfeeding can reduce } \\
\text { the risk of HCV transmission } \\
\text { - } 70.8 \% \text { believed that HCV could be spread via patient-to-patient } \\
\text { contact }\end{array}$ \\
\hline $\begin{array}{l}\text { Ipsos (2012) (16) } \\
\text { Canada }\end{array}$ & $\begin{array}{l}\text { Cross-sectional study } \\
\text { GPs/Family } \\
\text { practitioners } \\
\text { ( } \mathrm{n}=300 \text { ) } \\
\text { (Setting unknown: } \\
\text { information not } \\
\text { available) }\end{array}$ & $\begin{array}{l}\text { Information not } \\
\text { available }\end{array}$ & $\begin{array}{l}\text { Knowledge } \\
\text { - } 96 \% \text { of GPs agreed that many HCV-infected people are not aware of } \\
\text { their infection } \\
\text { - } 35 \% \text { of GPs know a lot about symptoms associated with HCV } \\
\text { infection } \\
\text { - } 10 \% \text { of GPs know a lot about available treatments } \\
\text { - } 43 \% \text { correctly identified that hepatitis C is curable; } 22 \% \text { were unsure }\end{array}$ \\
\hline
\end{tabular}


Appendix 1: Description of included studies $(n=19)$ (continued)

\begin{tabular}{|c|c|c|c|}
\hline $\begin{array}{c}\text { Author(s), year } \\
\text { of publication / } \\
\text { Country }\end{array}$ & $\begin{array}{c}\text { Study design / } \\
\text { Population / setting }\end{array}$ & $\begin{array}{l}\text { Method of data } \\
\text { collection }\end{array}$ & Outcome / Findings \\
\hline \multicolumn{4}{|c|}{ Health care providers $(n=6)$ (continued) } \\
\hline $\begin{array}{l}\text { McGowan et al. } \\
\text { (2013) (23) } \\
\text { Canada, Central/ } \\
\text { Eastern Europe, } \\
\text { Latin America, } \\
\text { Western Europe, } \\
\text { Nordic countries, } \\
\text { Asian/Pacific } \\
\text { countries, Middle } \\
\text { East/Africa, US }\end{array}$ & $\begin{array}{l}\text { Cross-sectional study } \\
\text { Physicians providing } \\
\text { HCV treatment } \\
\text { ( } n=697 \text { ) } \\
\text { International market } \\
\text { research database }\end{array}$ & $\begin{array}{l}\text { Phone interview or } \\
\text { self-administered } \\
\text { online questionnaire }\end{array}$ & $\begin{array}{l}\text { Knowledge } \\
\text { - Overall, a greater proportion of hepatologists knew about HCV } \\
\text { treatment than GPs } \\
\text { - Most physicians understood that different genotypes require different } \\
\text { treatment durations } \\
\text { - Most physicians understood that treatment should be discontinued in } \\
\text { patients who fail to achieve an early virologic response } \\
\text { - The majority of physicians incorrectly believed that HCV RNA levels } \\
\text { correlate with liver disease severity } \\
\text { - The majority of physicians also incorrectly believed that non- } \\
\text { responders should receive maintenance therapy } \\
\text { - } 40 \% \text { of providers believed that they have adequate knowledge of } \\
\text { treatment guidelines }\end{array}$ \\
\hline $\begin{array}{l}\text { Naghdi et al. (2017) } \\
(24) \\
\text { Canada }\end{array}$ & $\begin{array}{l}\text { Cross-sectional study } \\
\text { Primary care } \\
\text { physicians, specialists, } \\
\text { hepatology nurses and } \\
\text { nurse practitioners } \\
(n=163) \\
\text { Convenience sample } \\
\text { through provider } \\
\text { organizations }\end{array}$ & $\begin{array}{l}\text { Self-administered } \\
\text { questionnaire (online) }\end{array}$ & $\begin{array}{l}\text { Knowledge } \\
\text { - } 78 \% \text { of primary care physicians were not comfortable initiating } \\
\text { hepatitis C therapy } \\
\text { - } 70 \% \text { of primary care physicians expressed discomfort about switching } \\
\text { patients from one therapy to another } \\
\text { - Compared with primary care physicians, hepatologists, } \\
\text { gastroenterologists, hepatology nurses and nurse practitioners } \\
\text { expressed greater comfort in monitoring patients' current therapy } \\
\text { - } 22 \% \text { of primary care physicians had low awareness of current } \\
\text { coverage for HCV treatment }\end{array}$ \\
\hline $\begin{array}{l}\text { Rotte et al. (2013) } \\
(25) \\
\text { US }\end{array}$ & $\begin{array}{l}\text { Observational study } \\
\text { Residents, physicians, } \\
\text { nurse practitioners, } \\
\text { physician assistants } \\
\text { (n=78) } \\
\text { Emergency } \\
\text { departments }\end{array}$ & $\begin{array}{l}\text { Self-administered } \\
\text { questionnaire (online) }\end{array}$ & $\begin{array}{l}\text { Knowledge } \\
\text { - Knowledge of HCV consequences was high (percentage not } \\
\text { provided) } \\
\text { - } 81 \% \text { were unaware of medications that can cure HCV are available } \\
\text { - } 58 \% \text { were aware of the CDC HCV-related guidelines } \\
\text { - } 42 \% \text { were worried about contracting HCV while working in the } \\
\text { emergency department } \\
\text { - } 67 \% \text { were more worried about contracting HCV from a needle-stick } \\
\text { injury than HBV or HIV } \\
\text { - } 71 \% \text { agreed that rapid HCV testing would be beneficial to their } \\
\text { patients } \\
\text { - } 40 \% \text { denied that health care providers with HCV could transmit HCV } \\
\text { to a patient }\end{array}$ \\
\hline $\begin{array}{l}\text { Todorova et al. } \\
(2015)(26) \\
\text { Bulgaria }\end{array}$ & $\begin{array}{l}\text { Cross-sectional study } \\
\text { Dental medicine } \\
\text { students ( } n=96) \\
\text { Faculty of Dental } \\
\text { Medicine, Medical } \\
\text { University of Varna, } \\
\text { Bulgaria }\end{array}$ & $\begin{array}{l}\text { Self-administered } \\
\text { questionnaire }\end{array}$ & $\begin{array}{l}\text { Knowledge } \\
\text { - } 41.6 \% \text { had a good knowledge of HBV/HCV (score of } 8 / 10) \\
\text { - Aware of possible routes of transmission: } \\
-90.6 \% \text { knew about broken skin or blood transmission } \\
-62.5 \% \text { knew about broken skin or saliva } \\
-87.5 \% \text { knew about needle injury } \\
\text { - Intact skin in contact with saliva }(87.5 \% \text { ) and intact skin in contact with } \\
\text { intact skin ( } 90.6 \% \text { ) were correctly considered as not dangerous for } \\
\text { HBV/HCV transmission and respectively } \\
\text { - } 80 \% \text { knew that HBV/HCV carriers may look healthy and not show } \\
\text { symptoms }\end{array}$ \\
\hline
\end{tabular}

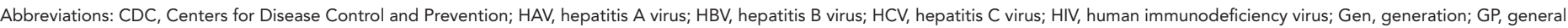
practitioner; MSM, men who have sex with men; NHANES, National Health and Nutrition Examination Survey; n, number; RNA, ribonucleic acid; US, United States

${ }^{a}$ A number of studies were included in the systematic review 